\title{
$\mathrm{Oz}$
}

$1-1-2015$

\section{Honoring Place, Detail, and Intent: A Case Study}

David Ericsson

Lake | Flato Architects

Follow this and additional works at: http://newprairiepress.org/oz

Part of the Architecture Commons

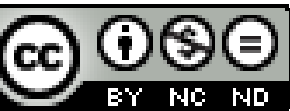

This work is licensed under a Creative Commons Attribution-Noncommercial-No Derivative Works 4.0 License.

\section{Recommended Citation}

Ericsson, David (2015) "Honoring Place, Detail, and Intent: A Case Study," Oz: Vol. 37. https://doi.org/10.4148/2378-5853.1548

This Article is brought to you for free and open access by New Prairie Press. It has been accepted for inclusion in Oz by an authorized administrator of New Prairie Press. For more information, please contact cads@k-state.edu. 


\section{Honoring Place, Detail, and Intent \\ A Case Study}

\section{David Ericsson \\ Lake | Flato Architects}

York Mountain Winery, established in 1882 , is the oldest winery in the California Central Coast region. Epoch Wines acquired the property in 2010 - with ambitions to serve as patrons of the property and its iconic wine history, while adding their own layer to its ongoing use as a functioning winery. Lake Flato joined the team-partnering with Epoch's vision in enhancing York Mountain's sense of place. Drawing inspiration from the local vernaculars, Lake Flato wanted to create buildings that expressed a great amount of care, while still remaining subservient to the landscape. The architectural interventions at Epoch sought a heightened sense of craft, where honing in on the sense of place was accomplished through architectural detail, and its ability to express Epoch's overriding ambitions.

\section{Epoch Tasting Room: \\ Detail in Response to \\ History and Narrative}

York Mountain Winery acted both as a production facility and tasting room. Having been built over the last 100 years as a series of additions, the building had been left condemned after an earthquake in 2003. Lake Flato's strategy called for adapting the historic building into a tasting room facility. The original tasting room and barrel room would be restored, the fermentation room would be reconstructed, and the upper floor and roof would be reinterpreted. A material logic emerged within this process, where every required structural intervention became the root of a new architectural language. To create a dialogue between old and new, the existing timber and masonry are partnered with concrete and steel to narrate the preservation of York Mountain's legacy.

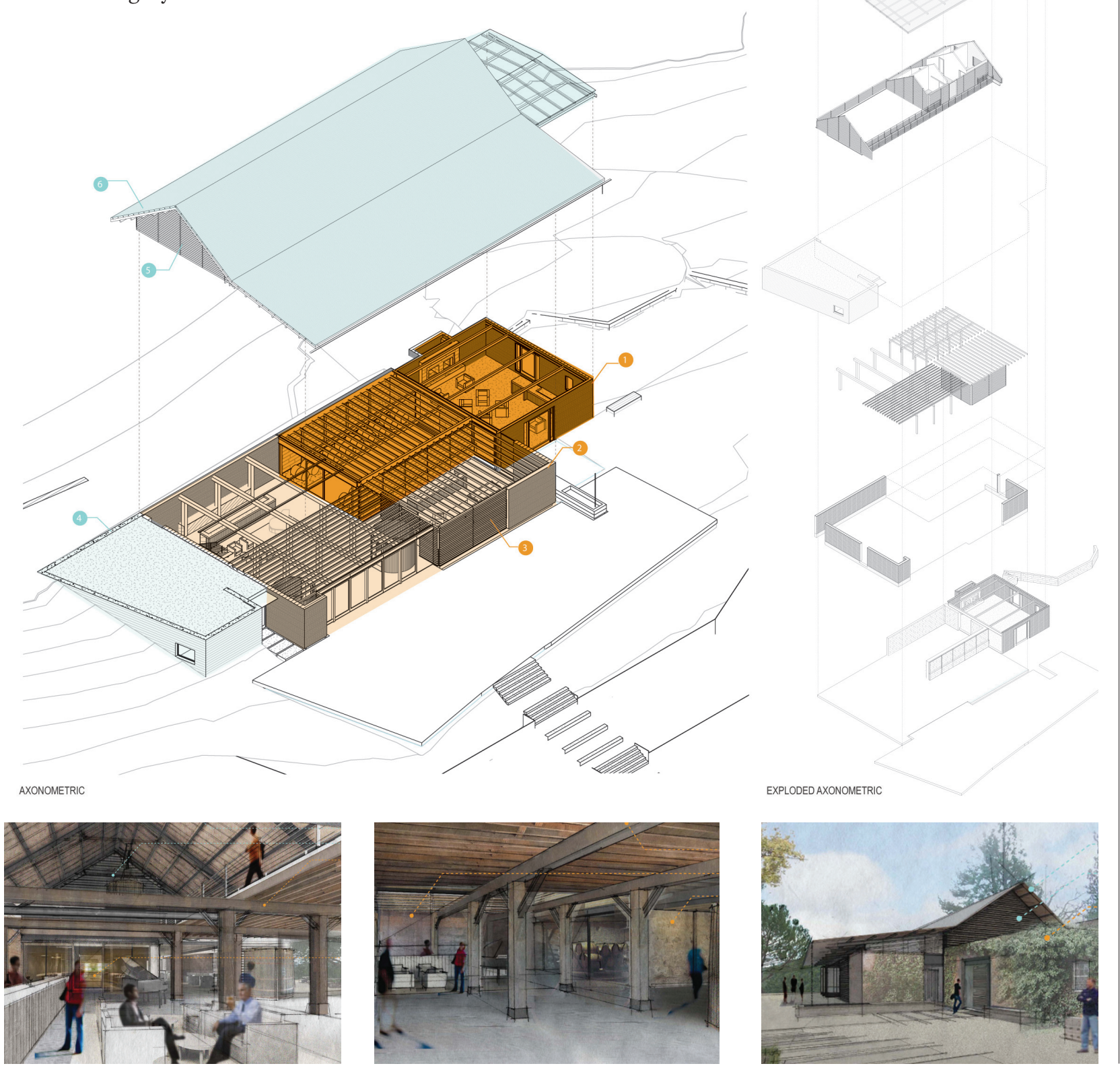



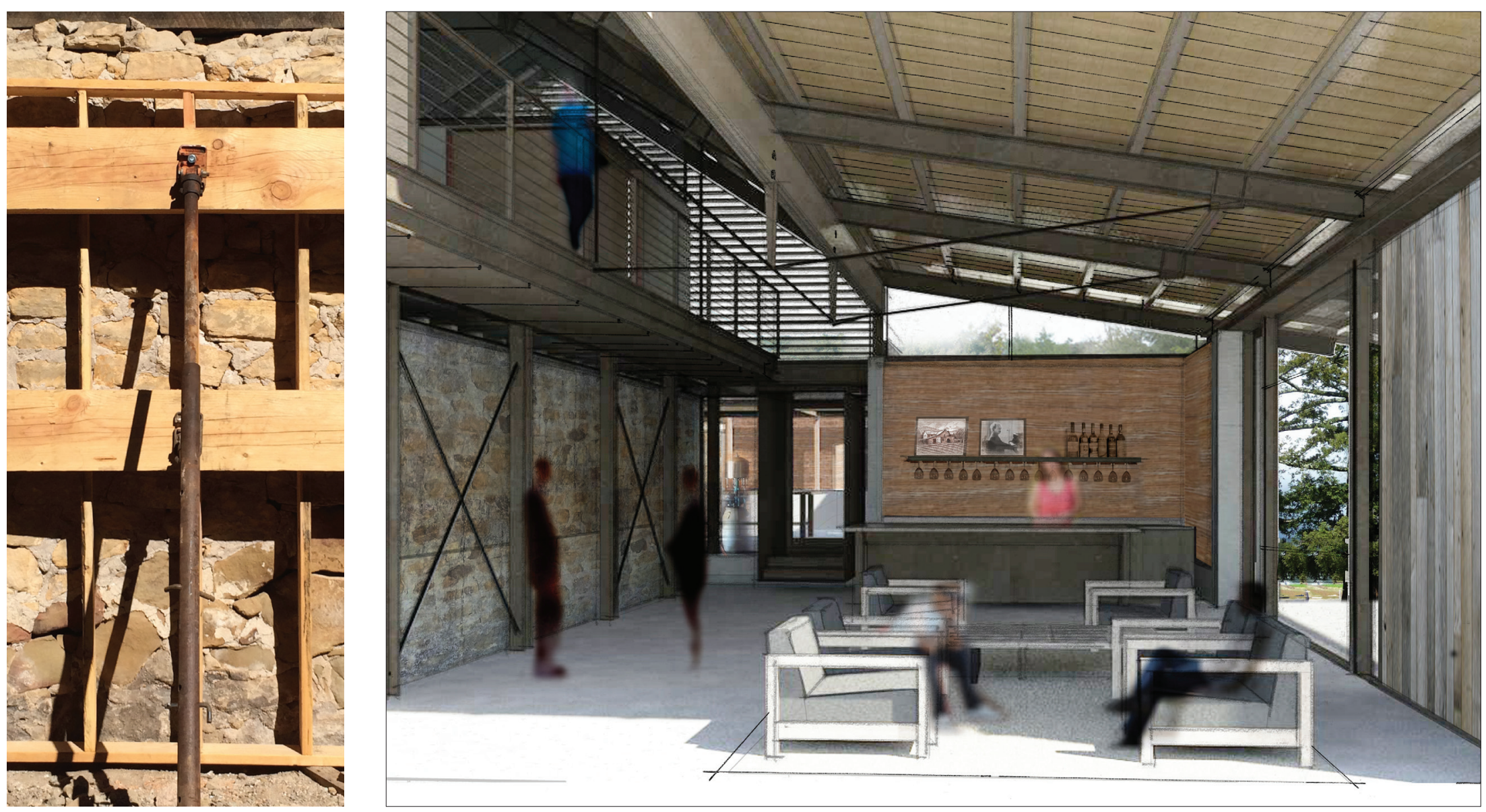

\section{Detail A:}

\section{Restoration}

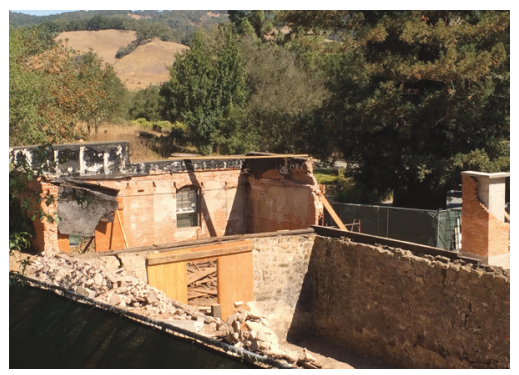

The un-reinforced masonry walls around the existing tasting room and barrel storage will be augmented with steel framing. The steel framework bolstering these walls became an integral part of the architecture. In the tasting courtyard, the steel is offset within the interior of the masonry, providing a structure to set new slatted-steel gates within. This also provides an overhead framework to support climbing vegetation and lighting. Outside of the barrel room, the steel framework (jokingly reffered to as "headgear") is offset from the stone wall, with the steel vertically dying into an eight-inch gravel channel, acting as a reveal between the new slab and the old wall. Expressing these structural interventions with craft helped narrate the intent of honoring these existing relics. 

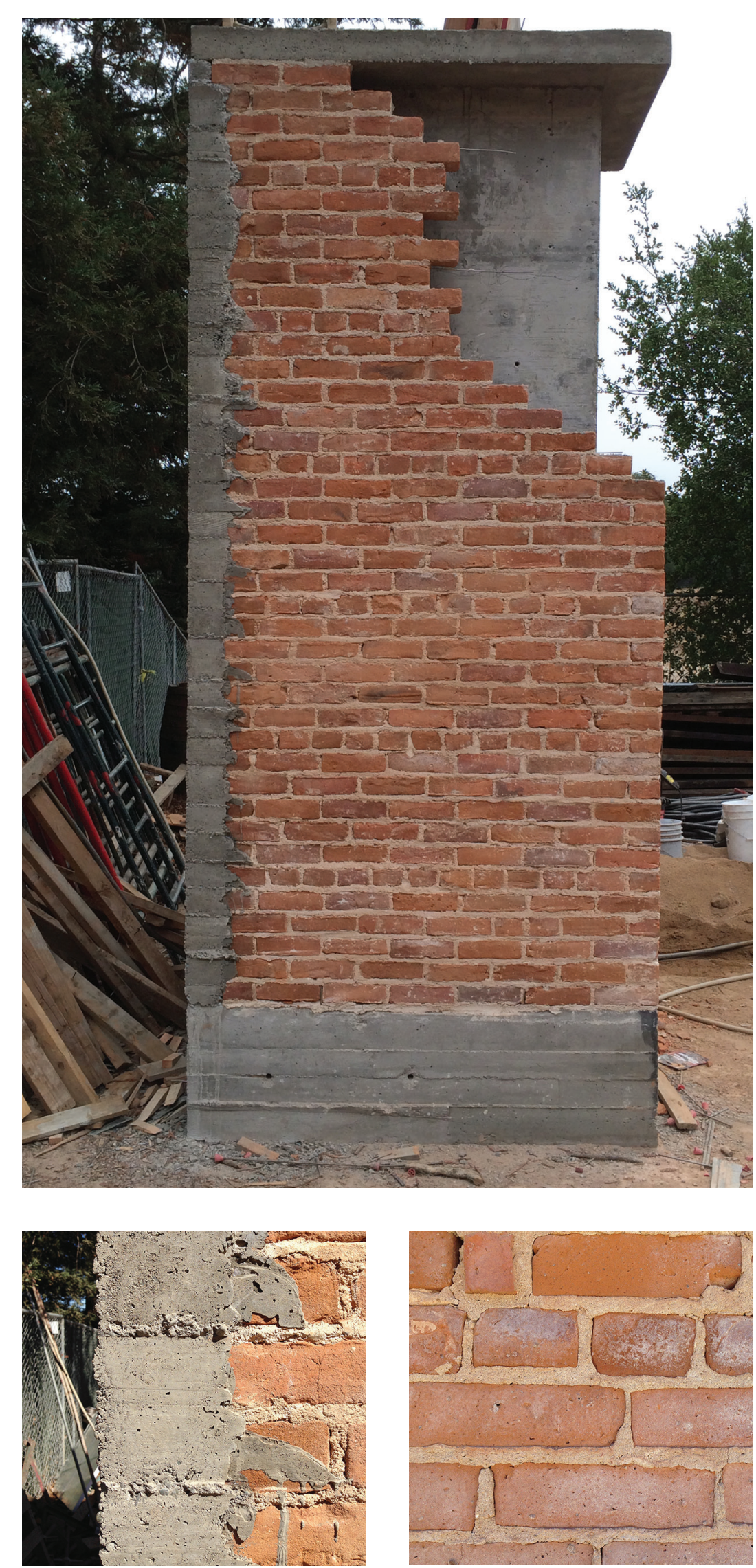
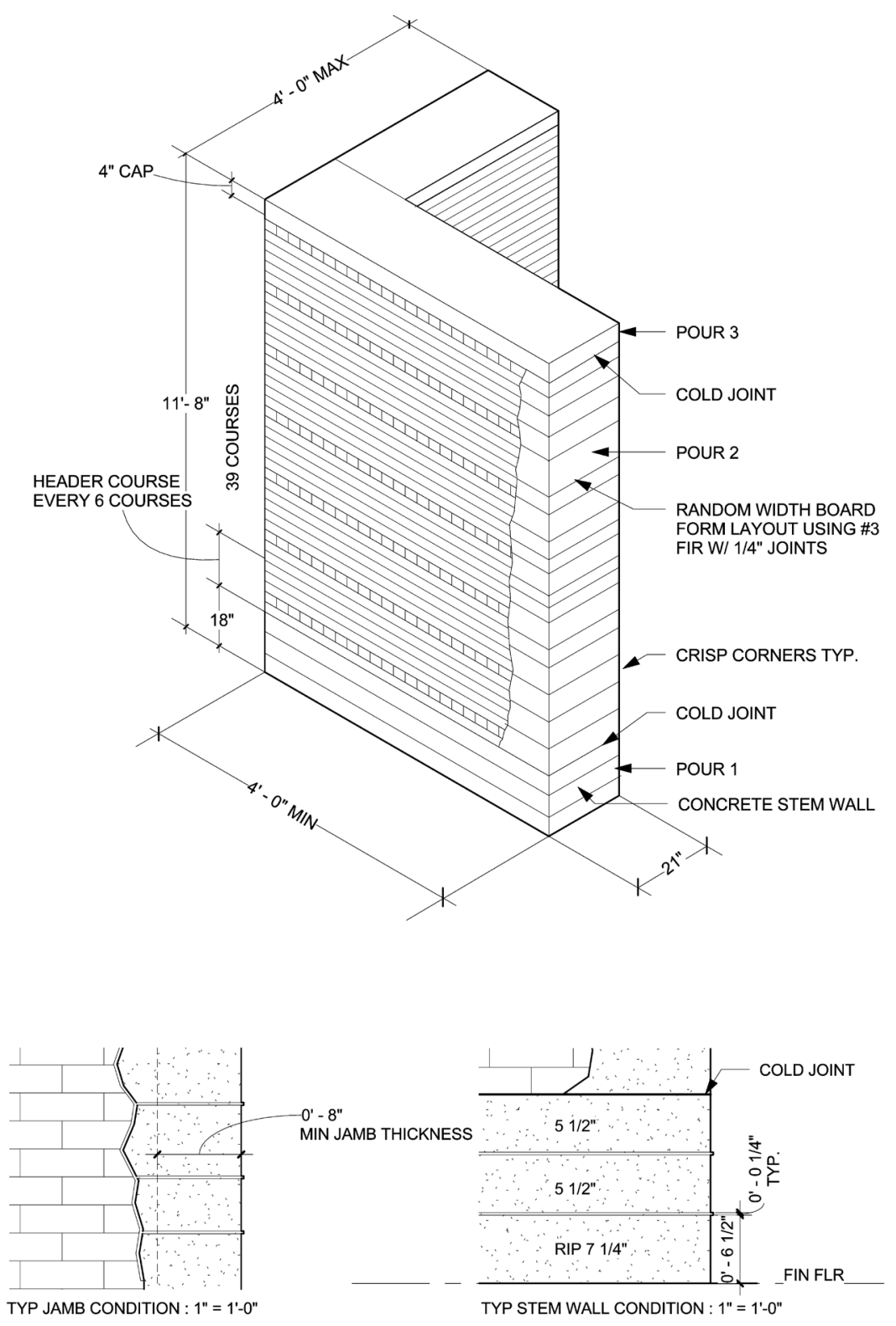

Detail B:

\section{Reconstruction}

The existing fermentation room will house the main tasting area for Epoch. The masonry walls are being rebuilt as concrete core walls to meet structural demands. The distinctive brick bond, coursing, and irregular mortar joints are being incorporated in the new walls, with board-formed concrete jambs at the openings. These walls sit on an 18-inch concrete stem, which helps to mitigate the change in floor level from the existing winery. This dimension traces over to the re-incorporated timber columns that sit on 18-inch tall concrete pedestals. Expressing these small shifts in concrete helps narrate the latest interventions in York Mountain's ongoing history. 


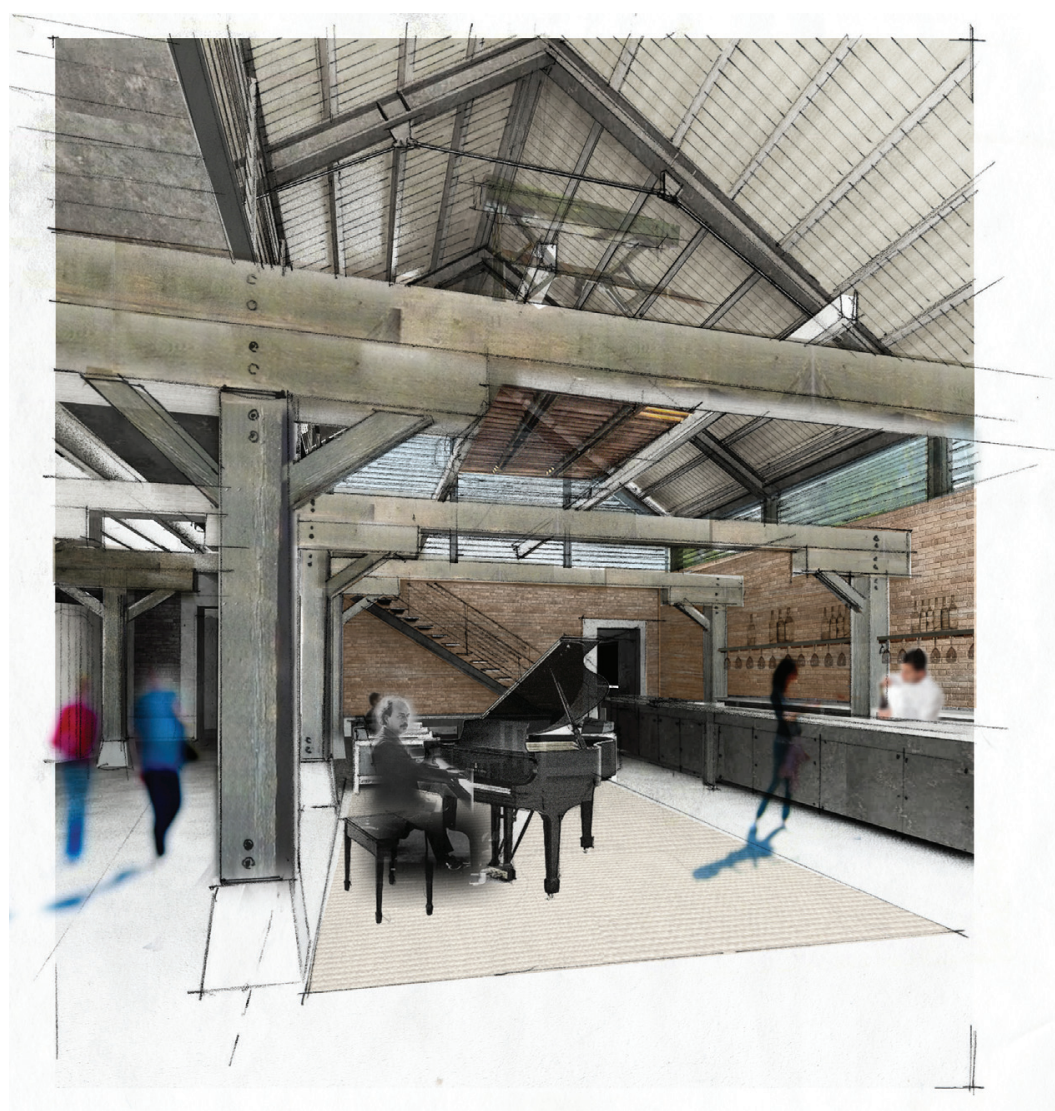

\section{Detail C:}

\section{Reinterpretation}

Lake Flato proposed a simplified roof shape, with offices located above the barrel room on a new mezzanine. Steel trusses are incorporated with a layered roof assembly of reclaimed-fir purlins and decking. This structure ties back to a large timber-and-steel queen post that spans the length of the barn. Steel-framed timber slat screens

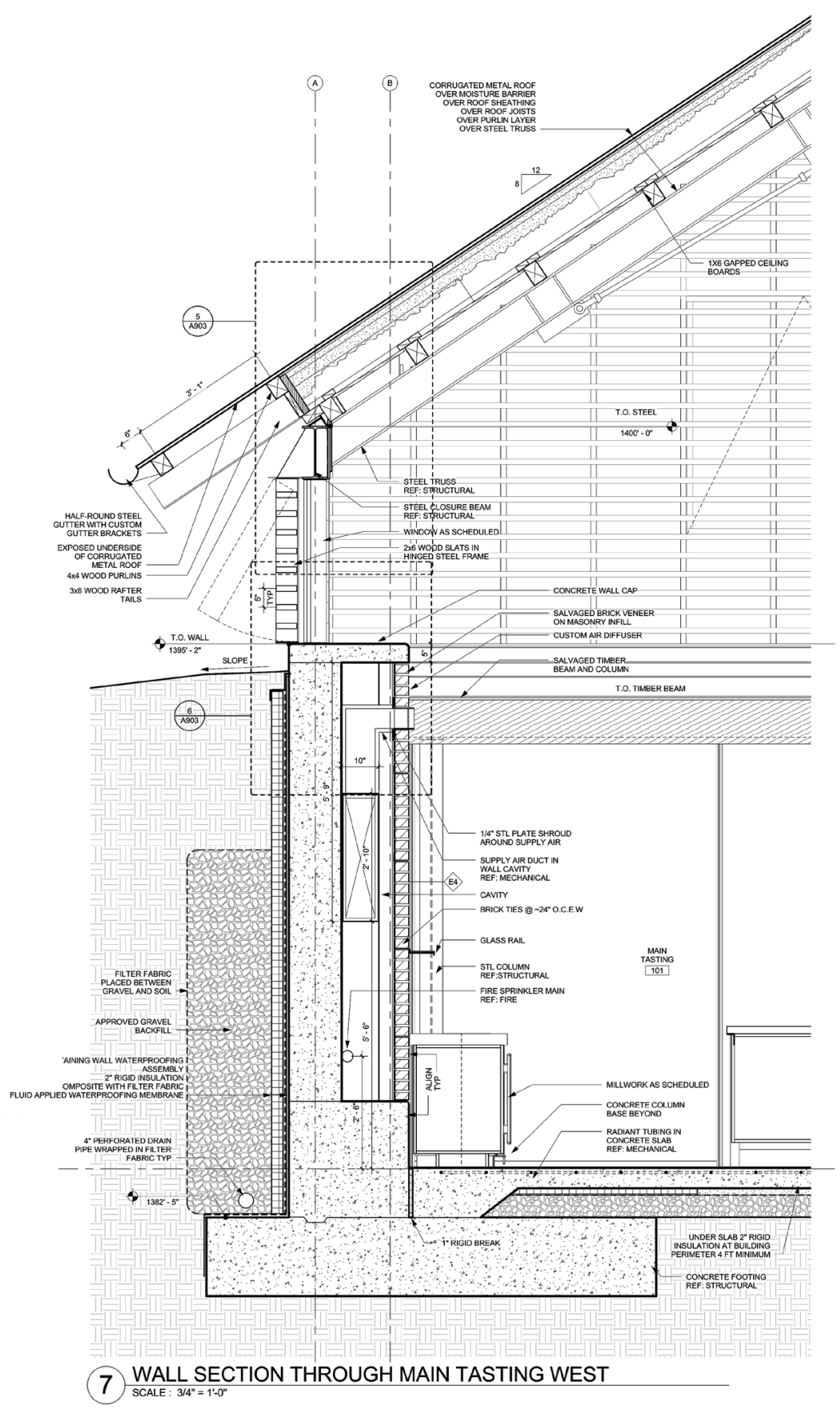




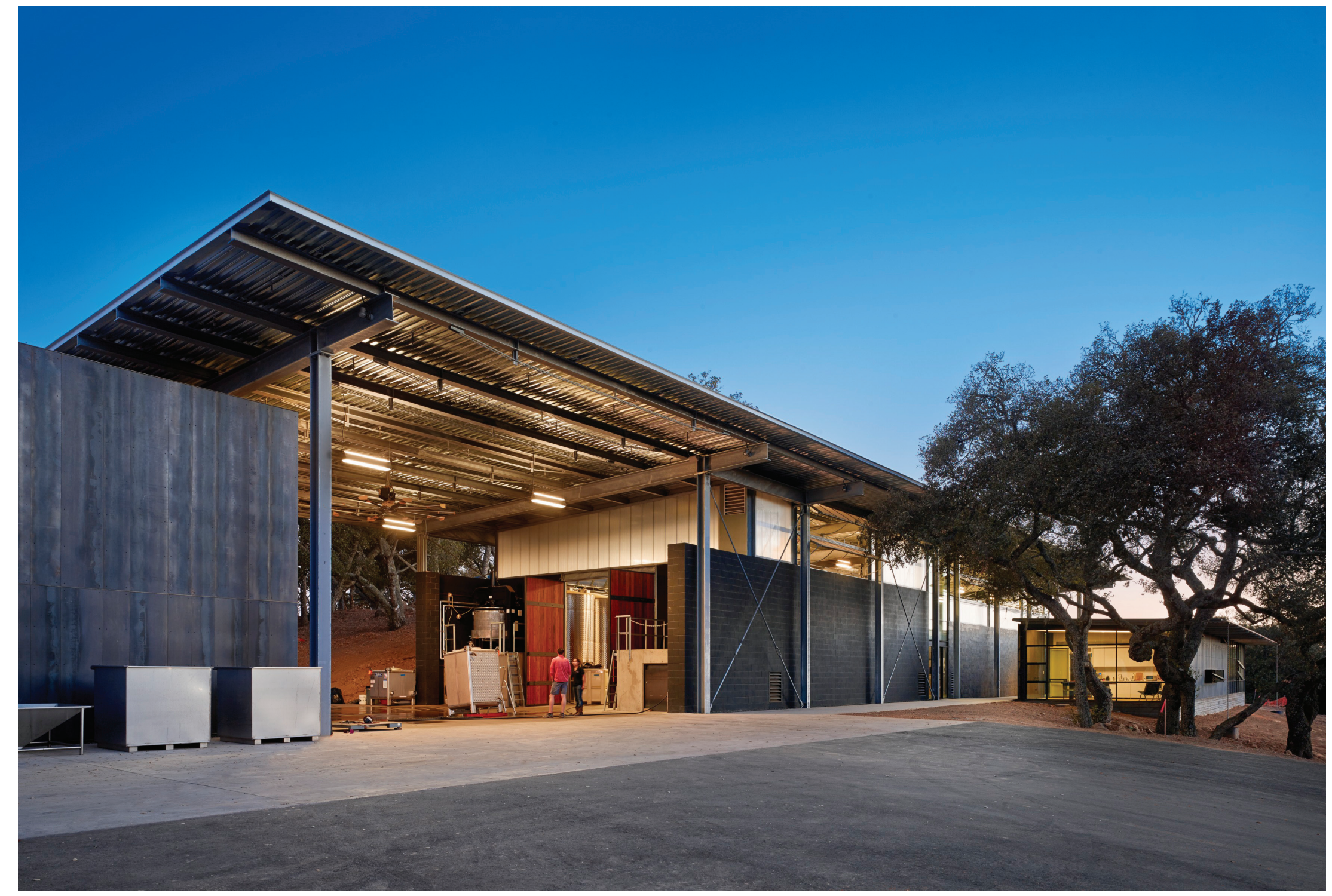

\section{Epoch Estate Wines:}

\section{Architecture Detail in Response} to Process and Utility

Lake Flato's design for Epoch's wine production facility hinged on re-using the existing structures, fitting into the site's natural surroundings, and celebrating Epoch's winemaking process. Lake Flato reused and expanded a nondescript masonry structure as a tank room. Its new roof extends and to the west to accommodate the entrance to the subterranean barrel aging room, with an administration building to the north. With a design intent to support the winemaking process, a dialogue emerged between the equipment and the detail-where every architectural intervention became rooted in the process itself. 


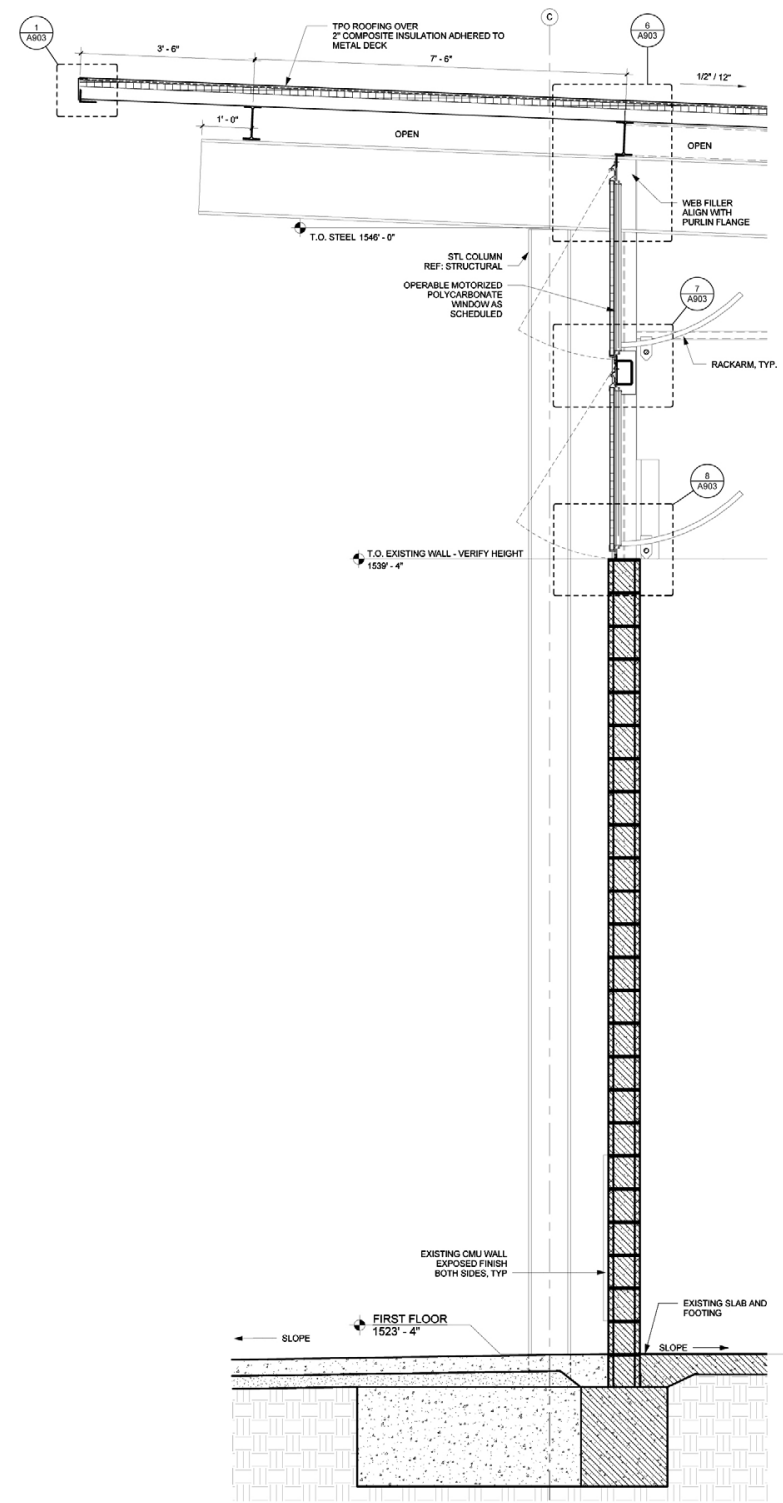

\section{Detail A:}

\section{Fermentation}

Epoch's fermentation room housed an existing masonry shell, with a large metal deck roof supported by outboard columns. A series of fermentation tanks of varying sizes sits on platforms, accommodating a gravity-fed winemaking process. For the board-formed concrete tanks, an integrated concrete platform was designed. A clerestory level of operable awning windows takes advantage of nighttime cooling, and their rack arms and pinions create dialogue with the catwalk system and its accompanying equipment. This even includes the fallprotection hardware that ties back to the structure. Exposed utilities
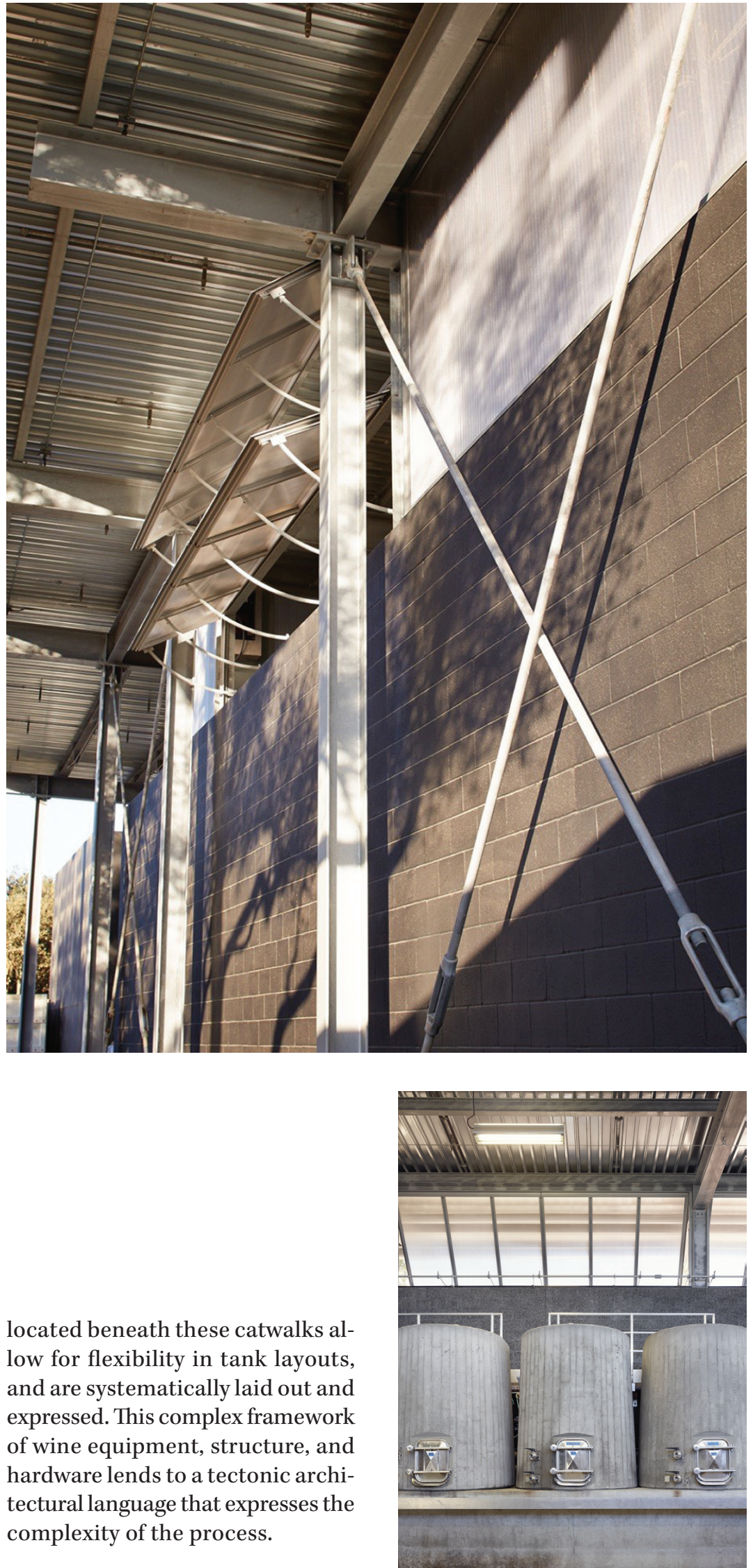


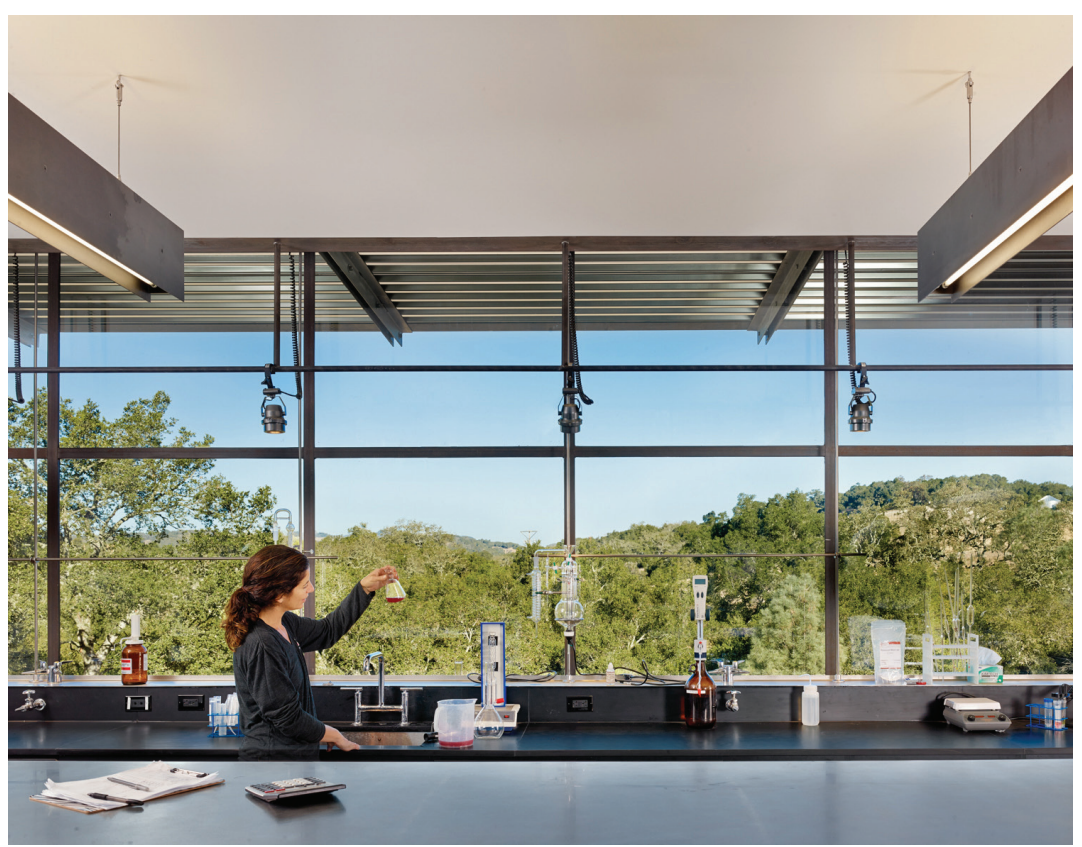

Image: Casey Dunn Photography

\section{Detail B:}

\section{Administration Function}

The detailing of the administration building is derivative of the main tank room, but with but with detailing that responds to the human scale. This is evident in the wine lab, where the same metal deck roof is expressed, but now supported by double angle out-lookers aligning with a steel window system that acts as a lens to the process. This steel window system incorporates which also acts as a functionally supportive clamp for lab equipment. The same functionally supportive framework shows up in additional administration spaces housing adjustable clamp lights, working in tandem with custom steel linear light fixtures. Expressing the craft in these frameworks helps to express the beauty in their utility. an internal steel rod "scaffolding"

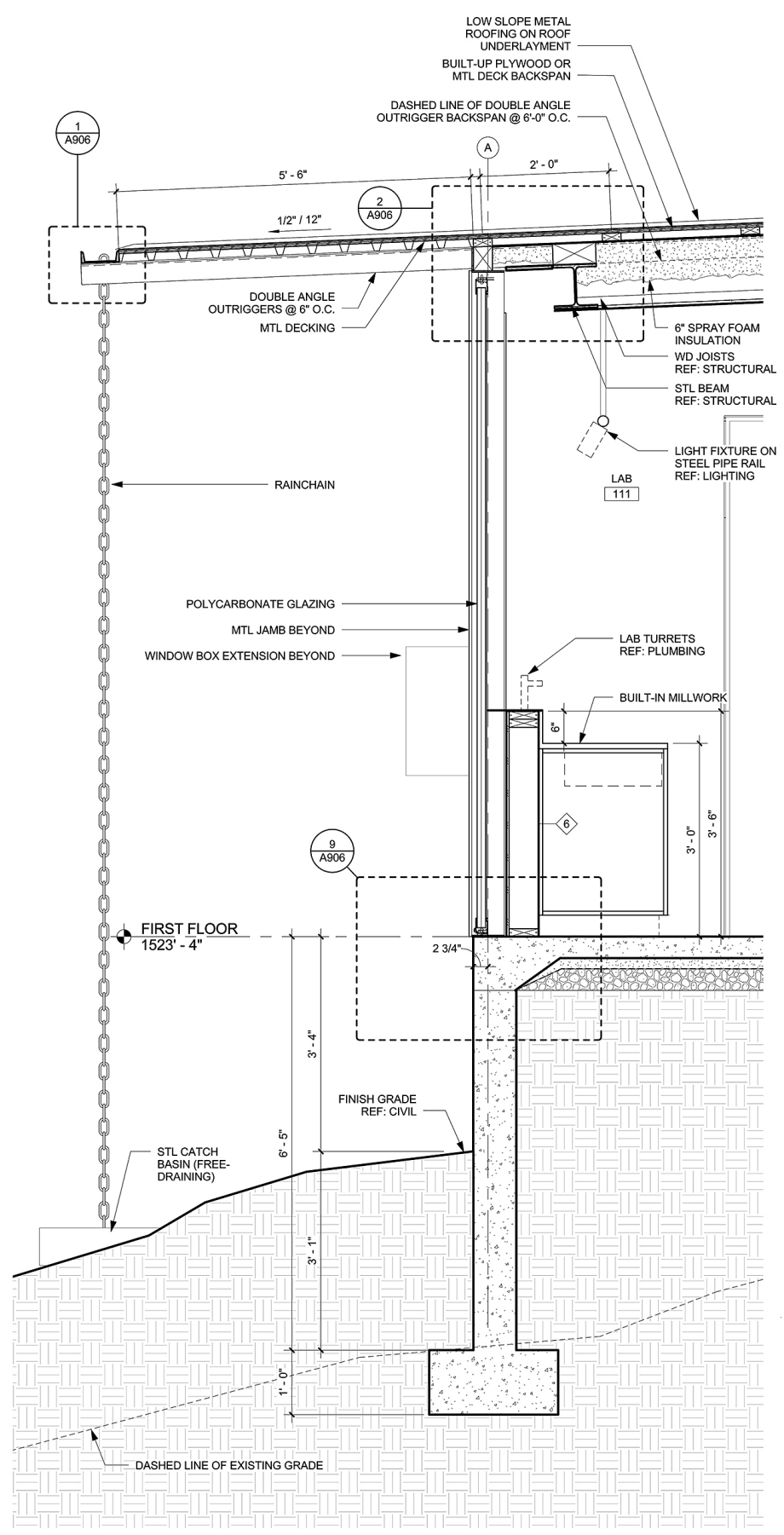




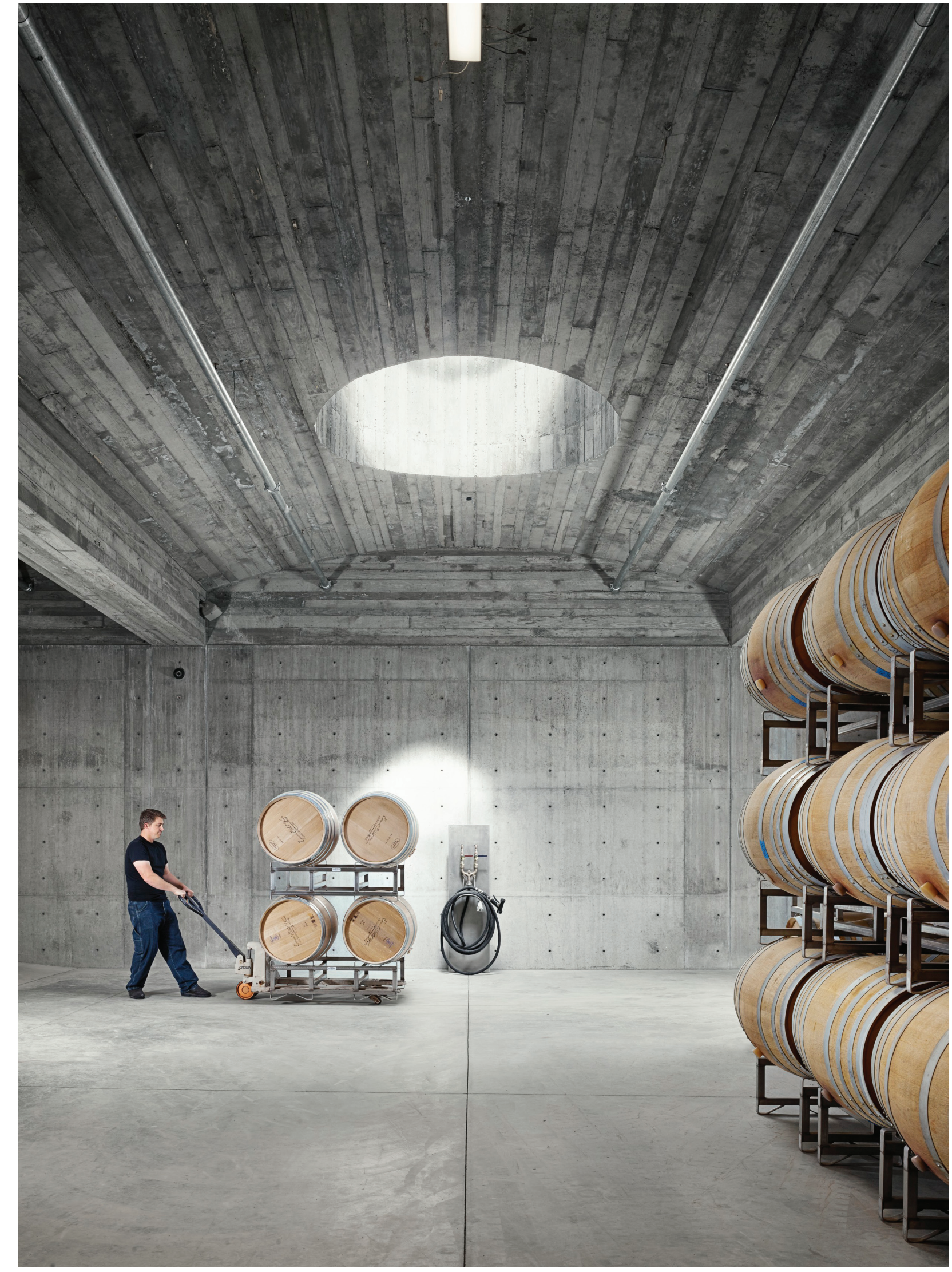

Image: Casey Dunn Photography

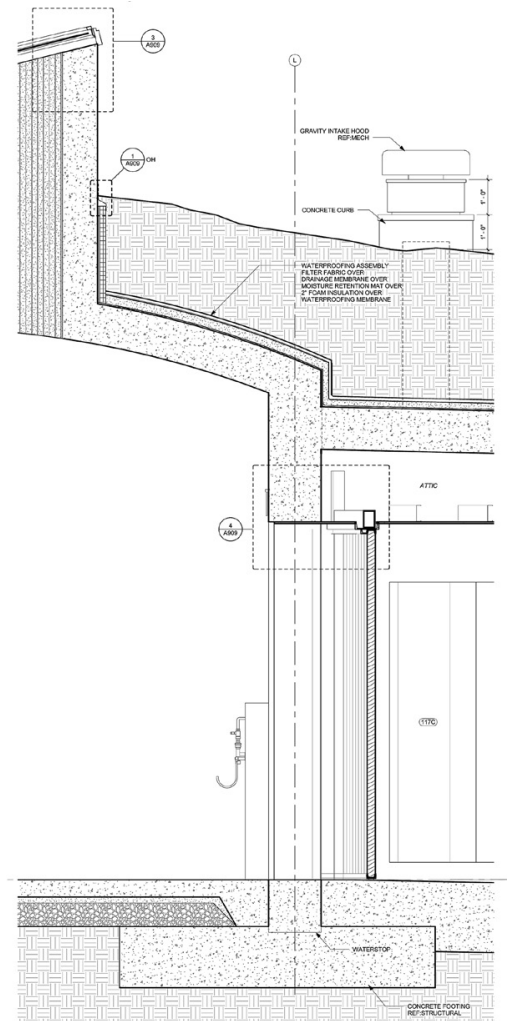

\section{Detail C:}

\section{Barrel Room Function}

Lake Flato placed the barrel room underground to minimize the complex's visual impact on the site, and to take advantage of the stable ground temperature. This underground room is built as a concrete bunker, with panel-formed concrete walls, and a board-formed, barrel-vaulted lid. Simply put, this part of the winery serves as a space for barrel aging. Hose stations, with custom-designed steel housings, line the perimeter of the space, and two large oculi bring light into the space, marking the hill above.

These two buildings were able to use architectural detail as an opportunity to celebrate both the winemaking legacy and process. 